\title{
There has been very little progress in treating or preventing antipsychotic-induced tardive dyskinesia
}

Citation for published version (APA):

van Harten, P. (2018). There has been very little progress in treating or preventing antipsychotic-induced tardive dyskinesia. Evidence-based mental health, 21(3), E10-E10.1. https://doi.org/10.1136/ebmental2018-300006

Document status and date:

Published: 01/08/2018

DOI:

10.1136/ebmental-2018-300006

Document Version:

Publisher's PDF, also known as Version of record

Document license:

Taverne

Please check the document version of this publication:

- A submitted manuscript is the version of the article upon submission and before peer-review. There can be important differences between the submitted version and the official published version of record.

People interested in the research are advised to contact the author for the final version of the publication, or visit the DOI to the publisher's website.

- The final author version and the galley proof are versions of the publication after peer review.

- The final published version features the final layout of the paper including the volume, issue and page numbers.

Link to publication

\footnotetext{
General rights rights.

- You may freely distribute the URL identifying the publication in the public portal. please follow below link for the End User Agreement:

www.umlib.nl/taverne-license

Take down policy

If you believe that this document breaches copyright please contact us at:

repository@maastrichtuniversity.nl

providing details and we will investigate your claim.
}

Copyright and moral rights for the publications made accessible in the public portal are retained by the authors and/or other copyright owners and it is a condition of accessing publications that users recognise and abide by the legal requirements associated with these

- Users may download and print one copy of any publication from the public portal for the purpose of private study or research.

- You may not further distribute the material or use it for any profit-making activity or commercial gain

If the publication is distributed under the terms of Article $25 \mathrm{fa}$ of the Dutch Copyright Act, indicated by the "Taverne" license above, 


\section{There has been very little progress in treating or preventing antipsychotic-induced tardive dyskinesia}

\section{Peter van Harten}

Dr Peter van Harten, Maastricht University School for Mental Health and Neuroscience Division Neuroscience, Maastricht 6229 ER, The Netherlands; pnvanharten@gmail.com

Commentary on: Bergman $\mathrm{H}$, Walker DM, Nikolakopoulou A, et al. Systematic review of interventions for treating or preventing antipsychotic-induced tardive dyskinesia. Health Technol Assess 2017;21:1-218.

\section{WHAT IS ALREADY KNOWN ON THIS TOPIC}

Tardive dyskinesia (TD) is a relatively frequent side effect of long-term use of antipsychotics and there is conflicting evidence if the incidence of TD is lower with second-generation antipsychotics (excluding clozapine), compared with first-generation antipsychotics. Until now there is no evidence-based algorithm to prevent or to treat TD.

\section{METHODS OF THE STUDY}

This systematic review ${ }^{1}$ evaluated any intervention for treating or preventing deterioration of symptoms of antipsychotic-induced TD in adult patients. Included were all relevant studies, regardless of language, about adults who had used antipsychotic drugs for $\geq 3$ months and in whom the antipsychotic doses had been stable for at least 1 month. The authors included 112 randomised trials and eight prospective cohort studies. Seventy-nine separate interventions were the focus of the trials, whereas prospective cohort studies focused on comparing different strategies for antipsychotics. These were grouped into three broad categories: 1. Reducing antipsychotic dose. 2. Switching antipsychotic drug. (3) Adjunctive treatments in addition to antipsychotic drugs. If enough studies were substantively similar, a meta-analysis using fixed-effects analyses was carried out. The authors used the Grading of Recommendations, Assessment Development and Evaluation approach to assess the quality of the evidence for the various interventions. Furthermore, a small consultation of people $(n=6)$ with TD/or at risk was planned to measure whether the outcomes of the studies matched service user priorities for managing TD.

\section{WHAT THIS PAPER ADDS}

- The low quality of many of the included trials prevents the construction of an algorithm for treating tardive dyskinesia

- The authors found low-quality evidence of (1) Clinically important improvement in TD symptoms after 12 weeks for switching antipsychotics to risperidone compared with withdrawing antipsychotics (with placebo) (one study, $\mathrm{n}=42$; RR $0.45,95 \% \mathrm{Cl} 0.23$ to 0.89 ) (2) After 6 weeks for buspirone compared with placebo while continuing antipsychotics as usual (one study, $n=42 ; \mathrm{RR} 0.53,95 \% \mathrm{Cl} 0.33$ to 0.84). Also low quality evidence was found for the use of vitamin $E$ to prevent deterioration of TD symptoms compared with placebo while continuing antipsychotics as usual after 1 year (five studies, $n=85$; RR $0.23,95 \% \mathrm{Cl} 0.07$ to 0.76 ).

- There is very low-quality evidence of clinically important improvement in TD symptoms (1) After 1 year of antipsychotic reduction compared with antipsychotic continuation (two studies $n=17$; RR $0.42,95 \% \mathrm{Cl}$ 0.17 to 1.04). (2) After 2 weeks of clonazepam compared with phenobarbital as active placebo while continuing antipsychotics as usual (one study, $n=21$; RR $0.44,95 \% \mathrm{Cl} 0.20$ to 0.96). (3) Hypnosis or relaxation compared with placebo while continuing antipsychotics as usual for eight sessions (one study, $n=15$; RR $0.45,95 \% \mathrm{Cl} 0.21$ to 0.94$)$.
- Service users $(n=6)$ with TD or at risk of developing TD recognised TD as a serious condition that could increase stigma. They were disappointed that many trials have been done without resulting in concrete evidence-based advice. They support that outcomes should also include issues such as social stigma.

\section{LIMITATIONS}

- An issue that is not addressed is that dyskinesia can be 'spontaneous'. Dyskinesia is also present in antipsychotic-naive patients with psychotic disorders. ${ }^{2}$ It has been suggested that 'spontaneous dyskinesia' in antipsychotic-naive patients should be considered as a symptom of psychotic disorders. ${ }^{3}$ Since there is no test, in patients using antipsychotics, to differentiate between drug-induced and 'spontaneous' dyskinesia, studies for TD will include both. It could be that each of these forms of dyskinesia requires different treatment. For example, if persisting dyskinesia is a psychotic symptom it could be that a switch to clozapine, which is often effective in treatment-resistant psychotic symptoms, is also effective is this form of dyskinesia and less in patients with drug-induced dyskinesia.

- Another issue that is not addressed is the substantial variability of TD over the years. Especially mild to moderate forms wax and wane, as is shown in the longest follow-up cohort study of inpatients with TD. ${ }^{4}$

- This systematic review does not differentiate between TD and tardive dystonia. Tardive dystonia is often more physically invalidating than tardive dyskinesia and the treatment also differs. ${ }^{5}$

\section{WHAT NEXT IN RESEARCH}

The author's suggest a need for large, long-term randomised-controlled trials or cohort studies and give more advice to increase the quality of the trials. Future research should use electronic instruments to assess the severity of tardive dyskinesia . Instrumental measurement is objective (lacks observer bias), highly reliable (IRR around 0.9), very sensitive (can detect subclinical TD), offers a continuous outcome, may be used in portable devices and requires minimal training. ${ }^{4}$

Although this systematic review does not include a switch to clozapine as one of the 10 interventions prioritised, a recent systematic review shows that patients often benefit with such a switch. ${ }^{6}$

\section{DO THESE RESULTS CHANGE YOUR PRACTICES AND WHY?}

No. Due to the disappointing results, this systematic review does not offer treatment options for patients with TD. However, in our specialised movement disorders clinic in Amersfoort (the Netherlands) we often see patients with severe forms of TD or tardive dystonia. We do treat them, and our clinical experience is that especially switching the antipsychotic used to clozapine or adding VMAT-2 inhibitors (tetrabenazine, valbenazine, deutetrabenazine) is often helpful. ${ }^{7}$

Funding The authors have not declared a specific grant for this research from any funding agency in the public, commercial or not-for-profit sectors.

Competing interests None declared.

Provenance and peer review Commissioned; internally peer reviewed.

(C) Author(s) (or their employer(s)) 2018. No commercial re-use. See rights and permissions. Published by BMJ. 


\section{doi:10.1136/ebmental-2018-300006}

Received 31 May 2018; Revised 19 June 2018; Accepted 20 June 2018

\section{REFERENCES}

1. Bergman H, Walker DM, Nikolakopoulou A, et al. Systematic review of interventions for treating or preventing antipsychotic-induced tardive dyskinesia. Health Technol Assess 2017;21:1-218.

2. Walther S, Strik W. Motor symptoms and schizophrenia. Neuropsychobiology 2012;66:77-92.

3. van Harten PN, Walther S, Kent JS, et al. The clinical and prognostic value of motor abnormalities in psychosis, and the importance of instrumental assessment. Neurosci Biobehav Rev 2017;80:476-87.
4. Mentzel CL, Bakker PR, van Os J, et al. Effect of Antipsychotic Type and Dose Changes on Tardive Dyskinesia and Parkinsonism Severity in Patients With a Serious Mental IIIness: The Curaçao Extrapyramidal Syndromes Study XII. J Clin Psychiatry 2017:78:e279-e285.

5. Skidmore F, Weiner WJ. Burke R: Neuroleptic-induced tardive dyskinesia variants. in Drug Induced Movement Disorders. Edited by Factor SA, Lang AE, Weiner WJ. Massachusetts, Blackwell Publishing 2005:257-85.

6. Mentzel T0, van der Snoek R, Lieverse R, et al. Clozapine monotherapy as a treatment for antipsychotic-induced tardive dyskinesia: A meta-analysis. J Clin Psychiatry 2018.

7. Stegmayer K, Walther S, van Harten P. Tardive Dyskinesia Associated with Atypical Antipsychotics: Prevalence, Mechanisms and Management Strategies. CNS Drugs 2018;32:135-47. 